Wspomnienia 



\section{Studia Witolda Stefańskiego z zakresu językoznawstwa klasycznego}

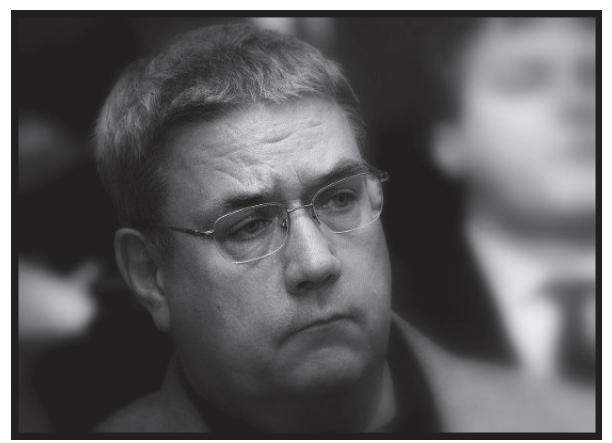

Witolda Stefańskiego pamiętać będziemy jako człowieka o wyjątkowo rozległych zainteresowaniach, a zarazem jako badacza, o którego nie bez racji upominać się mogą przynajmniej cztery specjalności naukowe. W punkcie wyjścia swego rozwoju naukowego oraz w znacznej mierze w jego etapach końcowych - romanista, z postępem studiów - badacz zgłębiający zawiłości logiki formalnej, w głównym nurcie swych zainteresowań - językoznawca teoretyk, zmierzający z postępem czasu w stronę indoeuropeistycznych studiów porównawczych, był również Stefański znaczącym reprezentantem szacownej swą wielowiekową tradycją filologii klasycznej.

Filologiem klasycznym był Witold Stefański w zupełnie profesjonalnym znaczeniu tego określenia, gdyż nie poprzestając na uzyskanym wcześniej wykształceniu romanistycznym, podją w roku 1976 w macierzystym Uniwersytecie Adama Mickiewicza studia filologii klasycznej, które zakończył cztery lata później rozprawą magisterską System fonetyczny języka łacińskiego na podstawie „De litteris, de syllabis, de metris” Terentianusa Maurusa, napisaną pod kierunkiem profesora Ignacego Lewandowskiego. Już temat owej pracy magisterskiej wskazuje na to, że zainteresowania badawcze młodego adepta filologii klasycznej zmierzają syntetycznie ku problematyce ję- 
zykoznawczej, w zakresie której realizuje się on później jako badacz i pracownik nauki.

W czasie wspomnianych studiów Witold Stefański dał się jednak poznać również jako doskonały kompan i aktywny uczestnik życia towarzyskiego kierunku, zarazem jako kolega w trudniejszych chwilach niosący towarzyszom studiów niezawodną pomoc. Ci, z którymi studiował, wspominają go także jako błyskotliwego uczestnika wspólnych dociekań naukowych i młodego badacza wyjątkowo dokładnego w swych ustaleniach, a z drugiej strony obdarzonego swego rodzaju zmysłem, czy też nabytą zdolnością interdyscyplinarnego ujmowania zagadnień ${ }^{1}$.

Jest mocno prawdopodobne, że właśnie w trakcie odbywanych przez siebie studiów filologii klasycznej młody Witold Stefański zainteresował się poważniej problematyką językoznawczą, a znakomity impuls tym jego zainteresowaniom dał kontakt $\mathrm{z}$ dziełem dla językoznawstwa prekursorskim i w znacznej mierze fundamentalnym, jakim jest Platoński „Kratylos”. Przypomnijmy, że jest to utwór podejmujący kwestię pewnej „prawidłowości”,

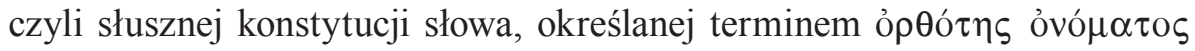
i przynoszący kilka istotnych w tym względzie rozwiązań ${ }^{2}$. Witold Stefański pracował początkowo nad tym dialogiem Platona w ramach zajęć translatorskich i seminaryjnych, w których uczestniczył, a praca zaabsorbowała go na tyle, że podjął się - co jest ewenementem - samodzielnego tłumaczenia „Kratylosa” na język polski, na co nie zdobył się nawet tak wytrawny translator, jakim był Władysław Witwicki. Przekład tego dialogu Platona ukazał się drukiem dopiero w roku 1990, a więc dziesięć lat po ukończeniu studiów przez Witolda Stefańskiego, co umożliwiło mu doprowadzenie translacji do stanu, w mojej ocenie, w pełni satysfakcjonującego.

Trudność tłumaczenia „Kratylosa” na jakikolwiek inny język polega głównie na tym, że składają się na ten utwór w znacznej części osławione

${ }^{1}$ Opieram się głównie na relacji prof. Aleksandra Mikołajczaka, który w tym właśnie czasie również odbywał studia filologii klasycznej w poznańskiej uczelni.

2 Pierwsze z nich sprowadza ową, ,słuszność” słowa do tego, by jako swego rodzaju narzędzie - ,organon” jednoznacznie identyfikowało przedmiot oraz pełniło bez zakłóceń swą funkcję komunikacyjną, następne do tego, by nazwa jako skondensowany opis rzeczy informowała o jej właściwościach, natomiast trzecie czyni już z nazwy „obraz”„eikōn” nazywanego przedmiotu zawarty w brzmieniu wyrazu, a opierający się na dość niezwykłej semantyce dźwięków elementarnych. 
Platońskie etymologie, które Sokrates przedstawia w liczbie dokładnie $131^{3}$, polegające na asocjacjach fonetyczno-semantycznych, jakich niepodobna odnaleźć w żadnym z pozostałych języków. Tę trudność rozwiązał Witold Stefański w sposób moim zdaniem najbardziej racjonalny. Wychodząc z założenia, że nie ma tej samej „naturalnej prawidłowości” wyrazów „dla wszystkich, zarówno Hellenów jak i barbarzyńców" (Crat. 383a - tł. W. Stefański), zrezygnował z poszukiwania polskich odpowiedników dla powiązań brzmieniowo-znaczeniowych, jakie u Platona odnajduje Sokrates między wyrazami greckimi. Stefański tłumaczy możliwie wiernie treść łączonych przez niego w związki etymologiczne wyrazów greckich, natomiast ich brzmienie pozostawia nietknięte, a dokonuje tylko transkrypcji ich zapisu literowego. Dzięki temu zrozumiałe pozostają i sens, i postać Platońskich etymologii, a sam tłumacz usuwa się powściągliwie poza treść i literę przekazu. Ta powściągliwość i ograniczanie własnej inwencji stylistycznej jest generalnie właściwością przekładu „Kratylosa”, jakiego dokonuje Witold Stefański. Jest to tłumaczenie bardzo oszczędne w środkach wyrazu, stwarzające nawet wrażenie nieporadności stylistycznej, a z drugiej strony wyważone, precyzyjne i dostosowane do obecnych naszych standardów językowych oraz możliwości percepcyjnych współczesnego czytelnika. Dzięki temu przekład Stefańskiego, w moim przynajmniej przekonaniu, wychodzi zwycięsko z konfrontacji z drugim polskim tłumaczeniem „Kratylosa”, które - co jest wydarzeniem dość niezwykłym - ukazało się niemal w tym samym czasie ${ }^{4}$, a nawet z natchnionym niemieckojęzycznym przekładem Schleiermachera ${ }^{5}$. Pozwala w najmniej kłopotliwy sposób docierać do treści Platońskich rozważań o poprawności słowa zarówno nieprzygotowanemu merytorycznie odbiorcy, jak też czytelnikowi o aspiracjach filologiczno-językoznawczych.

Można przyjać, że z owej pracy translatorskiej, lecz i z badawczej refleksji nad Platońskim dialogiem wyrosły w znacznej mierze przyszłe rozległe studia językoznawcze Witolda Stefańskiego, który zaczął iść w tym

3 Por. Z. Danek: Jest jakaś słuszność słowa... O platońskim dialogu Kratylos, Łódź 1995 , s. 48.

4 Jest to przekład pióra Zofii Brzostowskiej, opatrzony doskonałą przedmową Michała Kaczmarkowskiego (Plato, Kratylos, tłum. Z.Brzostowska, Lublin 1990).

5 Por. Platon. Sämtliche Werke Bd. 3: Kratylos, Parmenides, Theaitetos, Sophistes, Politikos, Philebos, Briefe. Übers. v. Friedrich Schleiermacher, 2-te verbesserte Auflage, Berlin 1824. 
kierunku już jako początkujący romanista, jednak dopiero pogłębiony kontakt z „Kratylosem” Platona nadał zdecydowany kierunek jego lingwistycznym zainteresowaniom, a pogłębiona znajomość greki, będąca rezultatem owego kontaktu, dała doskonałą podstawę jego przyszłym badaniom językoznawczym. Swoje pierwsze studia związane z interpretacją Platońskiego dialogu skupił wprawdzie głównie na egzegezie tekstu, w interesujący sposób wykazując ironiczny stosunek Sokratesa, i tym samym autora dialogu, do roztaczanej przez niego pseudowiedzy etymologicznej ${ }^{6}$ czy wskazując na dwuznaczny: logiczny i „ontyczny” charakter Platońskiego określenia $\tau$ ò őv (Krat. 429d5) ${ }^{7}$, niemniej jednak już w pierwszej wzmiankowanej pracy dokonuje na przykład kompleksowej klasyfikacji dostrzeżonych przez Platona czynników, które leżą u podstaw przemian językowych (s. 43-45). Ten zmysł systematyka językoznawcy odzywa się w nim również wtedy, gdy w kolejnej swojej pracy poświęconej „Kratylosowi” zajmuje się bliżej alfabetem greckim, jaki wyłania się z rozległych dywagacji Sokratesa, poświęconych na przemian fonetycznej i graficznej postaci wyrazów greckich ${ }^{8}$. Witold Stefański porządkuje nazwy greckich liter, jakie można znaleźć w Platońskim tekście (wykazując brak w nim słownych określeń trzech znaków, mianowi-

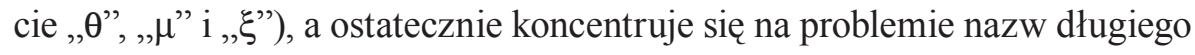
i krótkiego „o", skłaniając się w wyniku dokonanych zestawień do ich rozgraniczenia; tak, by dźwięk długi ujmowało „o”, krótki natomiast „u”.

Studia nad „Kratylosem” w niemałej mierze uczyniły z Witolda Stefańskiego językoznawcę i to językoznawcę, który imponuje rozległością perspektywy badawczej. Obok rozważań odnoszących się tematycznie do podstawowej $\mathrm{w}$ tej dyscyplinie problematyki indoeuropeistycznej, stworzył szereg prac poświęconych między innymi składni i morfologii języka portugalskiego, kwestiom gramatycznym dotyczącym języka iryjskiego, ekspresywności niektórych wyrażeń języka albańskiego, a nawet określonym rodzajom słów należących do języka gruzińskiego czy japońskiego. W tak rozległym spektrum badawczych zainteresowań Witolda Stefańskiego niemałą i znaczącą przestrzeń zajmują jego studia z zakresu językoznawstwa klasycznego, pojmowanego dość szeroko oraz interdyscyplinarnie.

6 W pracy: En lisant le Cratyle (Eos LXXIV/1 [1986], s. 39-47).

7 Mam na myśli pracę: Kratylos 429d. Über die Bedeutung von $\tau$ o öv. (Eos LXXV/2 - [1987], s. 91-93).

8 On the Names of the Letters Used in Plato's Kratylos (Eos LXXX/1 [1992], s. 53-60). 
Językoznawstwo klasyczne, które w zasadzie nie stanowi wyodrębnianej dyscypliny czy też specjalności naukowej, określimy jako refleksję badawczą skupioną na analizie i systematyzacji samego słownictwa i konstrukcji składniowych języków klasycznych, czyli łaciny i greki - taki będzie węższy sens tego określenia, w którym owe języki pozostają jedynie obiektem badań - lecz z drugiej strony także jako wychodzące ku innym językom i dyscyplinom nauki studia, w których języki klasyczne wchodzą w korelację z tymi systemami leksykalno-składniowymi oraz naukami, dostarczając materiału egzemplifikującego czy komparatystycznego i przez to stając się również niezbędnym często wyposażeniem językoznawcy $\mathrm{w}$ jego postępowaniu badawczym.

Witold Stefański uprawia językoznawstwo klasyczne w jednym i drugim znaczeniu słowa. Dowodem staje się szereg jego prac, w których niekiedy wyjaśnia komparatystycznie morfologię oraz praktyczny i etymologiczny sens określonych wyrazów greckich czy łacińskich, lecz z drugiej strony stosuje także niejednokrotnie zdobytą wiedzę na ich temat jako cenną broń w przezwyciężaniu podejmowanych problemów lingwistycznych i nie tylko lingwistycznych. Pierwszy nurt tych jego studiów reprezentuje (poza wspomnianym już artykułem poświęconym nazwom liter w „Kratylosie”) praca o charakterze w zasadzie gramatycznym, w której na sporej liczbie przykładów omawia występujące $\mathrm{w}$ grece klasycznej rozwiązania różnych relacji czasowo przestrzennych, jakie dokonują się z wykorzystaniem przyimków, konieczne w sytuacji zaawansowanego już w tym języku synkretyzmu przypadków i w jakiejś mierze prekursorskie w stosunku do analogicznej sytuacji, jaka ma miejsce w językach współczesnych ${ }^{9}$. W innym - krótkim, lecz pełnym treści - tekście podejmuje Witold Stefański problem latynistyczny, odnosząc się do morfologii łacińskiego superlatywu o zakończeniu ,-issimus” i etymologicznie wyjaśniając tę postać przyrostka jako połączenie skróconego komparatywnego ,ios” oraz cząstki ,somo/semo” oznaczającej szczególną kumulację branej pod uwagę cechy ${ }^{10}$. Daje do zrozumienia, że niezależnie od swych studiów językoznawczych wkraczających w dalekie obszary lin-

9 Jest to artykuł: Cas, préverbes et prépositions en ancien grec (Lingua Posnaniensis XXVI [1983], s.135-140).

10 Jest to praca: On the Origin of the Latin Superlative Suffix-issimus (Eos LXXX/1 [1992], s. 51). 
gwistyki i nauk jej pokrewnych pozostaje niezmiennie klasykiem - zarówno hellenistą, jak i latynista.

Poza obszar samej filologii i ściśle pojmowanego językoznawstwa wykracza jednak Witold Stefański dość wcześnie, mianowicie już w pracy poświęconej systemowi zdań warunkowych dawnego języka greckiego jako rozwiązaniom relacji logicznej znanej pod nazwą implikacji ${ }^{11}$. Jest to $\mathrm{w}$ zasadzie, jak wskazuje powyższy opis, rozprawa z zakresu logiki formalnej, omawiająca ujęcia rachunku zdań określonego powyżej typu, jakie pojawiają się w praktyce językowej i myśli teoretycznej dawnej Grecji i ostatecznie wiążąca jedno z drugim, to znaczy owe rozwiązania praktyczne ze stworzoną przez stoików definicją czterech relacji warunkowych, czyli „implikacyjnych". Niemniej i tu wielokrotnie czerpiąc z realiów składni greckiej pozostaje Witold Stefański klasykiem, a dywagując na temat sięgających prajęzyka koneksji cząstki őv (używanej w greckich okresach warunkowych „System ..., s. 57), jest nadal językoznawcą indoeuropeistą.

$\mathrm{Na}$ szersze jeszcze wody nieskrępowanej naukowej refleksji wypływa Witold Stefański w ramach swych studiów klasycznych w pracy „Pochwała Arystotelesa"12, w której z niezwykłym szacunkiem omawia wyłożone w Arystotelejskich „Kategoriach” ujęcie „morfosemantycznej” struktury całej naszej rzeczywistości jako istotne osiągnięcie filozofa ze Stagiry, odchodzące od idei Platona, lecz i odmienne swym bezpośrednim odniesieniem do rzeczywistości pozajęzykowej od późniejszej semantycznej interpretacji de Saussure'a (s. 39). Jak widać, i w tej rozprawie o tematyce w zasadzie ontologiczno-logicznej odzywają się akcenty językoznawcze, a obficie przytaczana terminologia grecka nie pozwala zapomnieć o klasycznym wykształceniu autora. Niewattpliwie klasyczna, lecz już religioznawcza, jest też problematyka jeszcze jednego zasługującego na wzmiankę artykułu, tekstu: Le panthéon grec à la lumière de la théorie de Dumézil ${ }^{13}$, w którym zgodnie z myślą

11 Pracę tę ogłosił Witold Stefański już w roku 1982 pod tytułem: Le système hypothétique en ancien grec et l' implication dans le calcul de propositons (Lingua Posnaniensis XXV [1982], s. 81-86), a w kilka lat później opublikował też jej „uaktualnioną” wersję polskojęzyczną (System warunkowy w języku starogreckim oraz implikacja w klasycznym rachunku zdań, w: Struktura logiczna rozumowań lingwistycznych: praca zbiorowa - red. Jerzy Pogonowski; Tadeusz Ziółka, Wyd. PTPN (Prace Komisji Językoznawczej, t. 16), Poznań 1990, s. 53-63.

12 Zamieszczonej również w piśmie „Eos” (LXXXII/1 [1994], s. 37-45).

13 Praca ta również znalazła się w piśmie „Eos” (LXXXI/1 [1993], s. 43-46). 
wzmiankowanego w tytule Dumezila, a wbrew zastrzeżeniu J. Haudry'ego (s. 44) konstatuje Witold Stefański, że i w religii greckiej odnajdziemy „Dumezilowską" trójcę bóstw - w osobach Zeusa, Posejdona i Hadesa - nie do końca oddającą wprawdzie triadyczny Platoński układ „,kapłani - żołnierze - producenci”, niemniej o wyraźnie rozgraniczanych kompetencjach (1) grożącej mocą pioruna potęgi, (2) panowania i dominacji oraz (3) pewnych wytwórczych już „metalurgicznych” umiejętności. Te dyspozycje trzech bogów wyczytuje Witold Stefański z etymologicznej treści ich imion, zamykając tym samym i niejako wieńcząc całe rozumowanie wyraźnym akcentem językoznawczym.

Dokonany powyżej krótki przegląd dokonań Witolda Stefańskiego w obszarze językoznawstwa klasycznego skłania ku temu, by z podziwem podkreślić jego zauważaną przez wielu interdyscyplinarność i zdolność wkraczania z refleksją badawczą w zakres tematyczny całej niemal szeroko pojętej humanistyki. Można też zaryzykować twierdzenie, że ową zdolność pewnego poruszania się w przedstawionej bardzo szerokiej - i jeszcze szerszej nie omówionej powyżej - tematyce zawdzięcza ten niezwykły badacz w niemałej mierze przygotowaniu, jakie dały mu odbyte studia filologii klasycznej. Pozostaje przykładem na to, jak użyteczna jest ta wiedza w różnych dziedzinach nauk humanistycznych. 
